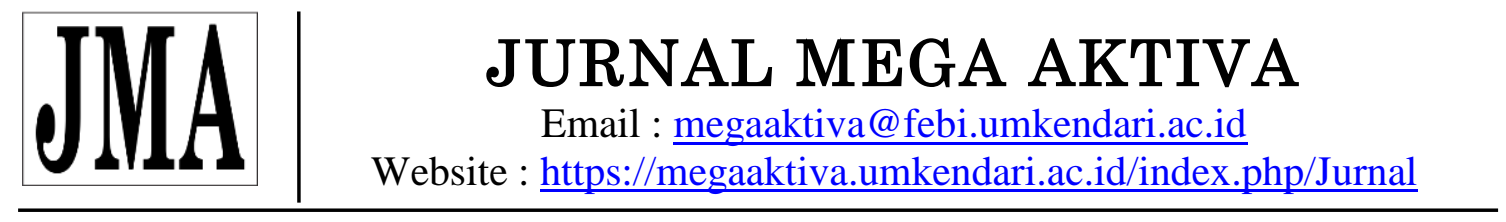

\title{
IDENTIFIKASI KOMODITAS UNGGULAN WILAYAH DALAM PERSPEKTIF PERTANIAN BERKELANJUTAN DI SULAWESI TENGGARA
}

\author{
${ }^{1}$ Zainal Abidin \\ ${ }^{1}$ Balai Pengkajian Teknologi Pertanian Sulawesi Tenggara \\ Jl. Prof. Muh. Yamin No. 89 Puwatu Kendari \\ Email : zainal.kdi@gmail.com
}

\begin{abstract}
ABSTRAK
Pengembangan komoditas pertanian di Sulawesi Tenggara memiliki khasanah spesifik yang berbasis pada kekhasan sumberdaya yang tersedia. Kajian dilakukan untuk mengetahui komoditas yang dapat menajadi basis pengembangan wilayah saat ini maupun secara berkelanjutan. Kajian di lakukan menggunakan data time series tahun 2010 - 2016. Penentuan komoditas basis menggunakn pendekan Location Quotien (LQ) dan Dinamic Location Quotient (DLQ). Hasil analisis menunjukkan bahwa secara umum komoditas tanaman pangan yang dapat menjadi basis di beberapa wilayah diantaraya adalah jagung, kacang tanah dan ubi kayu, sementara padi dan kedelai hanya menjadi basis saat ini, akan tetapi secara berkelanjutan akan mengalami pergeseran. Selanjutnya komoditas peternakan yang dapat menjadi basis adalah sapi, kambing, ayam kampung dan ayam petelur. Sementara itu komoditas perkebunan yang dapat menjadi basis adalah cengkeh, jambu mete, kelapa dalam, lada dan kakao, meskippun masing-masing wilayah memiliki karakteritisk tersendiri. Komoditas hortikultura yang dapat menjadi basis secara berkelanjutan adalah cabe besar, cabe rawit, jahe dan jeruk. Kedepan pengembangan komoditas pertanian yang menjadi sector basis baikd alam waktu saat ini maupun yang memiliki potenis menajdi basis secafra berkelanjutan perlu dioptimlkan dan di dukung dengan penerapan teknologi adaptif yang dapat diterima oleh masyarakat secara social dan memiliki nilai ekonomi yang dapat bersaing.
\end{abstract}

Kata Kunci : Komoditas Unggulan, Pertanian Berkelanjutan, Location Quotient

\section{ABSTRACT}

Developing of agricultural commodity at Southeast Sulawesi have specific ficture base on natural resources. The research was conducted to know the commodity that have sustainable competitifnes. Research was done using time series data 2010 - 2016 and analize with Location Quotien ( $L Q)$ dan Dinamic Location Quotient (DLQ) methode. The result of research show that food commoditeis that have become the sustaibnable bases commodity are corn, peanut and cassava, besides that rice and soybean only can became shor-term bases commodity. Livestock commodities such us sow, goat, native chicken and rusting hens broiler also can became bases commodity for a long time in several regencies. Even that clove, cashew nut, coconut, pepper and cocoa plantation can became the bases of commodities in several regencies such us Buton, Muna, Konawe Selatan, Kolaka Utara, Konawe Utara, Kendari dan Bau-Bau. Horticulture commodities such us chili pepper, zingeber and orange also can became sustainable bases commodities. So developing that commoditeis should be have policy supporting such us kredit regulation, infrasctukture and also aplicatif and simple technologies.

Keywords : supperior commodities, sustainable agriculture, Location Quotient. 


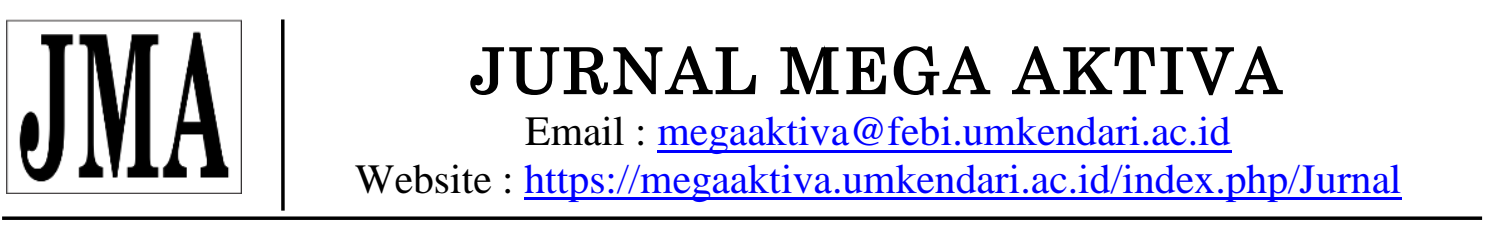

\section{PENDAHULUAN}

Undang-Undang No. 22 tahun 2004 tentang otonomi daerah sesungguhnya telah memberikan ruang yang lebih besar kepada daerah mengkreasikan diri berdasarkan potensi sumber daya yang dimiliki untuk berkembang secara berkelanjutan. Hal ini juga memberikan konsekuensi akan adanya disparitas pendapatan antar daerah. Perbedaan pendapatan daerah disebabkan oleh perbedaan sumberdaya alam, sumberdaya manusia dan perbedaan akses terhadap modal dan investasi, selain itu juga diakibatkan oleh adanya konsentrasi kegiatan ekonomi wilayah, alokasi investasi, mobilitasi factor produksi yang rendah antar daerah, perbedaan sumberdaya alam daerah, konsentrasi penduduk dan kurang lancarnya perdagangan antar daerah (Kuncoro, 2003; Oktavilia, 2009).

Daerah-daerah yang terletak dalam suatu wilayah luas tidaklah berkembang dalam intensitas dan kecepatan yang sama. Daerah yang memiliki faktor penentu dan faktor pendorong yang lebih banyak akan mampu berkembang lebih cepat dari pada daerah yang lain, dan sebaliknya daerah yang kurang memiliki faktor penentu dan pendorong akan relatif tertinggal dari daerah yang lain. Perraoux berpendapat bahwa pertumbuhan tidak muncul di berbagai tempat pada waktu yang sama, kemunculannya hanya akan terjadi di berbagai tempat atau pusat pertumbuhan dengan intensitas yang berbeda serta berkembang melalui saluran yang berbeda dengan akibat akhir yang ditimbulkan berbeda pula terhadap keseluruhan perekonomian (Nursyaman,1996 dalam Harjono, 2006).

Komoditas pertanian merupakan sumber pendapatan daerah yang dominan di Sulawesi Tenggara. Meskipun secara persentase peranannya terus turun dalam struktur Pendapatan Domestik Regional Bruto (PDRB), akan tetapi secara nominal terus tumbuh. BPS (2016) melaporkan bahwa kontribusi sektor pertanian mencapai $24,01 \%$, tertinggi dari 17 sub sektor ekonomi, meskipun kontribusi tersebut cenderung terus menurun. Lebih lanjut Abidin (2015) bahwa secara spesifik pertumbuhan subsektor dalam pertanian menunjukkan bahwa sub sektor tanaman perkebunan, tanaman pangan, perikanan dan peternakan terus tumbuh secara signifikan, sementara sub sektor kehutanan cenderung stagnan.

Pengembagan komoditas yang menjadi sektor basis dan memiliki kapasitas untuk bertumbuh secara signifikan akan mendorong pertumbuhan wilayah secara optimal. Hal ini berkesesuaian dengan konsep pengembangan pertanian berkelanjutan. Pentingnya aspek keberlanjutan adalah karena pertanian memiliki keterkaitan erat mulai efek rumah kaca, kwalitas air, penyerbukan, penyerapan karbon hingga penyediaan pangan serta ketersediaan lapangan kerja, dan sebaliknya praktek pertanian berkontribusi terhadap degradasi ekologis, perubahan iklim, kerusakan lahan hingga maupun akibat pencemaran pupuk phosfor dan nitrogen. (Tilman et al., 2011; Tscharntke et al., 2012; Liebman \& Schulte, 2015; West et al., 2014.

Pengembangan komoditas yang memiliki keunggulan spesifik wilayah akan menciptakan ruang yang kondusif dalam pengembangan pertanian berkelanjutan. Pada masing-masing sub sektor terdapat komoditas unggulan yaitu komoditas yang memberikan sumbangan terbesar dalam perekonomian dan pertumbuhan wilayah. Identifikasi komoditas unggulan penting dilakukan untuk menyusun road map pengembangan agar komoditas tersebut dapat terus tumbuh dan berkembang sebagai 
komoditas andalan wilayah. Identifikasi komoditas unggulan dapat di lakukan dengan menggunakan metode Location Quotient (LQ).

Kajian bertujuan untuk menganalisis dan memetakan komoditas unggulan masingmasing wilayah yang dapat didorong perkembangannya secara imperatif dan dapat menjadi pemicu perkembangan ekonomi wilayah.

\section{KAJIAN TEORITIS}

Dalam teori pertumbuhan ekonomi dikenal 2 sektor yaitu sektor basis dan non basis. Sektor basis adalah satu-satunya sektor yang bisa meningkatkan perekonomian wilayah melebihi pertumbuhan alamiah, sementara Sektor non basis adalah sektor yang sangat tergantung pada kondisi wilayah setempat dan tidak besa berkembang melebihi pertumbuhan ekonomi wilayah. Analisis basis dan non basis pada umumnya didasarkan atas nilai tambah (pendapatan) atau lapangan kerja. Teori basis ekonomi ini menyatakan bahwa faktor penentu utama pertumbuhan ekonomi suatu daerah adalah berhubungan langsung dengan permintaan akan suatu barang dan jasa dari luar daerah (Tarigan 2004: Tambunan 2001).

Todaro (1991) dalam Kuncoro (1997) mengemukkaan teori Perubahan Struktural yang menitik beratkan pembahasan pada mekanisme transformasi ekonomi yang dialami oleh negara sedang berkembang, yasng semula bertumpu pada sektor pertanian yang bersifat subsisten menuju ke struktur perekonomian yang lebih modern dan sangat didominasi oleh sektor industri dan jasa. Selanjutnya Lewis mengajukan teori tentang pembangunan yang membahas proses pembangunan yang terjadi antara daerah kota dan desa yang mengikutsertakan proses urbanisasi yang terjadi di antara kedua tempat tersebut. Teori ini juga membahas pola investasi yang terjadi di sektor modern dan juga sistem penetapan upah yang berlaku di sektor modern yang pada akhirnya akan berpengaruh besar terhadap arus urbanisasi yang ada.

Selanjutnya teori pembangunan berkelanjutan yang bertumpu pada tiga pilar yakni ekonomi, sosial dan ekologi yang memungkinkan pembangunan pertanian berlangsung dan mendukung terciptanya kesejahteraan masyarakat akibat andanya peningkatan nilai tambah produksi serta adanya efiseinsi sumber daya yang menghasilkan daya saing pada salah satu sisi dan tetap terpeliharanya lingkungan hidup pada sisi lainnya. Khusus untuk aspek dimensi lingkungan alam, menekankan kebutuhan akan stabilitas alam yang mencakup kehidupan biologis termasuk didalamnya terpeliharanya keragaman hayati dan daya dukung biologis, sumberdaya tanah, air dan agroklimat serta kesehatan dan kenyamanan lingkungan (Munasinghe, 1993; Haris, 2000 dalam Rivai dan Anugrah, 2011).

LQ adalah suatu perbandingan tentang besarnya peranan suatu sektor di suatu wilayah terhadap besarnya peranan sektor tersebut secara nasional (Tarigan, 2009). Secara umum menunjukkan lokasi pemusatan atau basis aktivitas dengan tujuan untuk melihat keunggulan komparatif suatu wilayah dengan dalam menentukan suektir andalannya. LQ dimanfaatkan untuk mengidentifikasi sumber-sumber pertumbuhan regional menganalisis kecenderungan dari faktor-faktor yang mempengaruhi hasil-hasil kegiatan ekonomi disuatu daerah dalam lingkup daerah himpunannya. Analisis LQ berguna untuk membantu menentukan kapasitas ekspor perekonomian daerah dan 
Email : megaaktiva@febi.umkendari.ac.id

Website : https://megaaktiva.umkendari.ac.id/index.php/Jurnal

melihat kemampuan daya saing komoditas antar daerah (Ma'mun D. dan Irwansyah S. 2013).

Sektor basis adalah sektor yang menjadi tulang punggung perekonomian daerah karena mempunyai keuntungan kompetitif (Competitive Advantage) yang cukup tinggi. Sedangkan sektor non basis adalah sektor-sektor lainnya yang kurang potensial tetapi berfungsi sebagai penunjang sektor basis atau service industries. Sektor basis ekonomi suatu wilayah dapat dianalisis dengan teknik Location Quotient (LQ), untuk mengetahui seberapa besar tingkat spesialisasi sektor basis atau sektor unggulan (leading sectors). Rusastra et al., (2002) bahwa yang dimaksud kegiatan basis merupakan kegiatan suatu masyarakatyang hasilnya baik berupa barang maupun jasa ditujukan untuk ekspor ke luar dari lingkungan masyarakat atau yang berorientasikeluar, regional, nasional dan internasional. Konsep efisiensi teknis maupun efisiensi ekonomis sangat menentukan dalampertumbuhan basis suatu wilayah.

\section{METODE PENELITIAN}

Penelitian dilakukan mengunakan data produksi komoditas pangan, perkebunan dan hortikultura dalam satuan ton, sementara untuk ternak menggunakan data populasi ternak dalam satuan ekor. Data produksi dan data populasi ternak yang menggunakan data tahun 2010 hingga tahun 2016. Metode analisis yang digunakan adalah :

a. Location Quotient (LQ)

Merupakan suatu analisis yang dapat memberikan indikasi kemampuan suatu daerah dalam menghasilkan suatu komoditas, apakah mempunyai potensi untuk men supply daerah lain, mendatangkan dari daerah lain, atau dalam keadaan seimbang. Teknik LQ relevan juga digunakan sebagai metode untuk menentukan komoditas unggulan khususnya dari sisi penawaran (produksi atau populasi) (Hendayana, 2003: Santosa et al., 2013). Secara matematis formula LQ adalah sebagai berikut :

$$
L Q=\frac{Y i j / Y j}{Y i n / Y n}
$$

Keterangan:

$\mathrm{Y}_{\mathrm{i}} \mathrm{j} \quad=$ Produksi sektor $\mathrm{i}$ di daerah $\mathrm{j}$

$\mathrm{Y}_{\mathrm{j}} \quad=$ Produksi seluruh sektor di daerah $\mathrm{j}$

$\mathrm{Y}_{\mathrm{i}} \mathrm{n}=$ Produksi sektor i di daerah $\mathrm{n}$ dimana daerah menjadi bagiannya

$\mathrm{Y}_{\mathrm{n}} \quad=$ Produksi seluruh sektor di daerah $\mathrm{n}$

\section{Kriteria}

1. Jika LQ $>1$, berarti sektor/subsektor tersebut merupakan sektor basis

2. Jika LQ $<1$, berarti sektor/subsektor tersebut merupakan sektor non basis atau sektor non unggul.

b. Dinamic Location Quotient

Pada dasarnya DLQ merupakan pengembangan lebih lanjut LQ dengan menggunakan data rata-rata pertumbuhan dalam kurun waktu tertentu (Agustono, 2013). Persamaan DLQ adalah :

$$
D L Q=\left\{\frac{(1+g i n) /(1+g n)}{(1+G t) /(1+G)}\right\}^{t}
$$




\section{JURNAL MEGA AKTIVA}

Email : megaaktiva@febi.umkendari.ac.id

Website : https://megaaktiva.umkendari.ac.id/index.php/Jurnal

Keterangan :

DLQ : Indeks Dynamic Location Quotient

gin : Rata-rata pertumbuhan produksi komoditi i di tingkat kabupaten $\mathrm{j}$

gn : Rata-rata pertumbuhan total produksi komoditi di tingkat kabupaten $\mathrm{j}$

$\mathrm{G}_{\mathrm{t}}$ : Rata-rata laju pertumbuhan produksi komoditi i di tingkat Provinsi

G : Rata-rata pertumbuhan total produksi komoditi i di tingkat Provinsi

t : Kurun waktu analisis

Kriteria :

1. DLQ > 1, sektor/subsektor pertanian masih dapat diharapkan untuk menjadi basis di masa yang akan datang.

2. DLQ $<1$, sektor/subsektor pertanian tidak dapat diharapkan untuk menjadi basis di masa yang akan datang.

c. Gabungan LQ dan DLQ

Analisis ini menggabungkan antara nilai dari LQ dan DLQ dengan kriteria sebagai berikut (Ariyani 2005) :

1. LQ $>1$ dan DLQ $>1$, maka sektor belum mengalami reposisi artinya sektor/subsektor yang menjadi basis pada saat itu juga masih menjadi basis dimasa mendatang.

2. LQ $>1$ dan DLQ $<1$, maka sektor/subsektor pertanian telah mengalami reposisi dan tidak bisa diharapkan untuk menjadi basis dimasa yang akan datang.

3. LQ < 1 dan DLQ > 1, maka sektor/subsektor pertanian telah mengalami reposisi dari sektor nonbasis menjadi sektor basis.

4. LQ $<1$ dan DLQ $<1$, maka sektor/subsektor pertanian belum mengalami reposisi dan tetap menjadi sektor non basis.

\section{HASIL DAN PEMBAHASAN}

\section{Dinamika Sektor Pertanian Di Sulawesi Tenggara}

Sektor pertanian di Sulawesi Tenggara masih merupakan salah satu sektor penting terutama dilihat dari sumbangsihnya terhadap PDRB yang masih tinggi serta kemampuan untuk menyerap tenaga kerja yang cukup besar (Abidin, 2015). Kontribusi sektor pertanian tidak terlepas dari perkembangan produksi berbagai komoditas pertanian baik pangan, ternak, perkebunan maupun hortikultra. Hal tersebut sebagaimana pada Gambar 1 .

Pada gambar 1 nampak bahwa pada umumnya laju pertumbuhan produksi komoditas pertanian per tahun dalam kurun waktu 6 tahun terakhir menunjukkan nilai yang positif dengan rata-rata laju pertumbuhan tertinggi adalah komoditi jahe dan yang terendah adalah kacang tanah. Tingginya rata-rata laju pertumbuhan komoditi jahe dipicu oleh semakin meningkatnya harga komoditas tersebut dalam beberapa tahun terakhir, sementara proses budidayanya relatif mudah. Sementara itu komoditi kacang tanah ratarata laju pertumbuhan produksinya menunjukkan negatif, yang berarti terjadi penuruan produksi. Hal ini disebabkan oleh semakin menurunnya areal pertanaman kacang tanah karena tergantikan dengan komoditi lain misalnya ubi kayu maupun kedelai. Selain itu produktivitas komoditi kacang tanah juga relatif menurun karena rendahnya penerapan teknologi terutama penggunaan varietas yang masih mengandalkan varietas lokal dan hanya di usahakan di beberapa kabupaten misalnya Muna dan Buton. 


\section{JURNAL MEGA AKTIVA}

Email : megaaktiva@febi.umkendari.ac.id

Website : https://megaaktiva.umkendari.ac.id/index.php/Jurnal

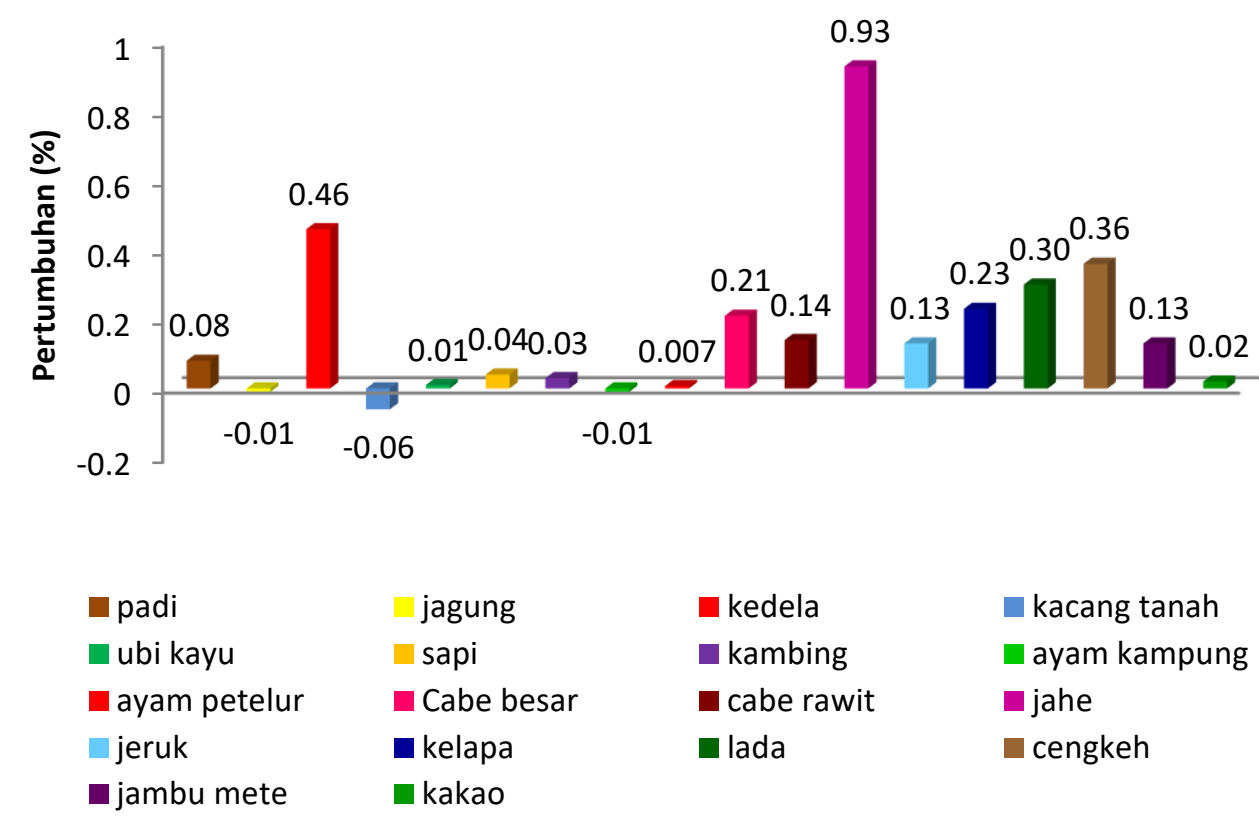

Sumber : BPS Sultra, 2010 - 2016; Dinas Pertanian, 2010 - 2016 (diolah)

Komoditi padi sawah sebagai salah satu komoditi strategis kementerian pertanian produksinya menunjukkan rata-rata laju pertumbuhan yang cukup signifikan. Hal ini dipacu oleh adanya program UPSUS padi dengan fokus penambahan areal pertanaman yang pada akhirnya akan mendorong pertumbuhan produksi. Namun demikian Jagung yang juga merupakan salah satu komoditas yang diupayakan swasembada produktsinya cenderung menurun. Hal ini karena petani belum mendapatkan insentif ekonomi yang memadai dan kadang kala produksi jagung sulit dipasarkan.

Komoditi jahe memiliki laju pertumbuhan rata-rata yang tertinggi. Hal ini meranik akrena tanaman ini tidak terlalu mendapatkan perhatian secara institusi dalam aritin tidak diberikan insentif peneyediaan benih, pupuk dan pstisida layaknya komoditas padi, Jagung dan kedelai, akan masayrakat secara mandiri mengembangkan komodiats tersebut secara luas. Hal ini dipicu oleh adanya insentif harga yang dapat diperoleh dari penanaman jahe tersebut yang mencapai Rp. 10.000 - Rp. 15.000 per kg, sementara produktvitasnya bisa mencapai hingga 15 - 20 ton per ha (BPS Sultra, 2015; Dinas Perkebunan dan Hortikjultura Sultra, 2016). Sehingga petani dapat memperoleh pendapatan yang cukup besar. Hal ini ditunjang pula oleh promosi dari beberapa perusahaan jamu yang menjadi pengumpul hasil dari komoditas tersebut.

a. Analisa Komoditas Basis

Komoditas basis adalah komoditas yang mampu memenuhi kebutuhan dalam wilayah bahkan memberi peluang untuk ekspansi ke wilayah lain. Komoditas basis dibagi pada masing-masing sub sektor pertanian yaitu tanaman pangan, ternak, perkebunan dan hortikultura. Hasil analisis LQ dan DLQ untuk komoditas pangan disajikan pada Tabel 1 yang menunjukkan bahwa bahwa sebagian besar kabupaten memiliki komoditas basis. Hal tersebut dapat ditandai dengan nilai LQ>1. Komoditi padi menjadi komoditas basis di Kabupaten Konawe, Kolaka, Konawe Selatan, Bombana, Kolaka Utara dan Bau-Bau. 
Email : megaaktiva@febi.umkendari.ac.id

Website : https://megaaktiva.umkendari.ac.id/index.php/Jurnal

Kabupaten tersebut memang dikenal sebagai produsen utama padi di Sualwesi Tenggara. Luas areal pertanaman padi sawah di Kabupaten Konawe, Konawe Selatan, Kolaka dan Kolaka Utara mencakup sekitar $80 \%$ dari luas areal sawah di Prov Sultra yang mencapai 126.000 ha (Dinas Pertanian Prov. Sultra, 2016). Namun demikian jika dilihat dari nilai DLQ $<1$ yang berarti bahwa secara jangka panjang komoditas tersebut belum bisa menjadi sektor basis, karena memiliki kecenderungan posisinya menurun. Hal ini karena adanya trend pertumbuhan yang relatif rendah. Oleh karena itu kebijakan peningkatan produksi melalui peningkatan produktivitas menjadi sangat penting terutama melalui penerapan teknologi.

Tabel 1. Hasil Analisis LQ dan DLQ Pada Komoditas Pangan Pada Masing-Masing Kabupaten di Sulawesi Tenggara, 2016

\begin{tabular}{|c|c|c|c|c|c|c|c|c|c|c|}
\hline \multirow[b]{2}{*}{ Kabupaten } & \multicolumn{2}{|c|}{ Padi } & \multicolumn{2}{|c|}{ Jagung } & \multicolumn{2}{|c|}{ Kedelai } & \multicolumn{2}{|c|}{ Kc. Tanah } & \multicolumn{2}{|c|}{ Ubi Kayu } \\
\hline & LQ & DLQ & LQ & DLQ & LQ & DLQ & LQ & DLQ & LQ & DLQ \\
\hline Buton & 0,25 & 1,08 & 1,55 & 1,28 & 0,55 & 1,00 & 0,29 & 1,02 & 3,23 & 1,19 \\
\hline Muna & 0,18 & 0,72 & 5,59 & 0,70 & 0,61 & 1,08 & 6,48 & 0,75 & 1,66 & 0,69 \\
\hline Konawe & 1,36 & 0,74 & 0,16 & 0,89 & 0,74 & 0,69 & 0,12 & 0,86 & 0,20 & 0,87 \\
\hline Kolaka & 1,27 & 0,58 & 0,47 & 0,81 & 0,92 & 0,82 & 0,44 & 0,56 & 0,37 & 0,59 \\
\hline Konsel & 1,18 & 0,61 & 0,46 & 0,79 & 1,70 & 0,95 & 0,27 & 0,61 & 0,65 & 0,60 \\
\hline Bombana & 1,31 & 0,42 & 0,41 & 0,74 & 0,63 & 0,77 & 0,33 & 0,38 & 0,26 & 0,41 \\
\hline Wakatobi & - & - & 0,24 & 0,37 & - & - & 0,04 & 1,34 & 4,55 & 0,25 \\
\hline $\begin{array}{l}\text { Kolaka } \\
\text { Utara } \\
\end{array}$ & 1,15 & 0,36 & 1,01 & 0,41 & 1,00 & 0,84 & 1,11 & 0,59 & 0,52 & 0,39 \\
\hline Buton utara & 0,34 & 0,32 & 0,79 & 0,44 & 3,31 & 0,56 & 0,41 & 0,64 & 3,15 & 0,37 \\
\hline $\begin{array}{l}\text { Konawe } \\
\text { Utara }\end{array}$ & 0,92 & 0,30 & 0,57 & 0,34 & 2,30 & 0,73 & 4,31 & 0,36 & 1,30 & 0,40 \\
\hline $\begin{array}{l}\text { Kota } \\
\text { Kendari }\end{array}$ & 0,52 & 1,61 & 1,72 & 1,26 & 0,01 & 0,91 & 1,31 & 1,21 & 2,28 & 1,33 \\
\hline $\begin{array}{l}\text { Kota Bau- } \\
\text { Bau }\end{array}$ & 1,21 & 0,61 & 0,28 & 0,89 & 0,02 & 0,41 & 0,07 & 1,43 & 0,67 & 0,67 \\
\hline
\end{tabular}

Komoditi jagung menjadi basis di Kabupaten Buton, Muna, Kolaka Utara dan Kota Kendari, bahkan di Kabupaten Buton komoditas ini bisa menjadi komoditas basis dalam jangka panjang. Hal ini ditandai dengan nilai LQ $>1$ dan DLQ $>1$. Kabupaten Buton memang merupakan salah satu daerah potensial pengembangan jagung pada lahan kering. Hal ini tidak terlepas dari keadaan sumberdaya lahan di Kabupten Buton yang didominasi oleh lahan kering berbatu, dan masyrakatnya menjadikan jagung sebagai salah satu pangan lokal mereka.

Komoditi kedelai menjadi basis di Kabupaten Konawe Selatan, Kolaka Utara, Buton Utara dan Konawe Utara. Wilayah tersebut memang dikenal sebagai daerah penghasil kedelai terutama di Kab. Konawe Selatan dan Buton Utara. Namun demikian dalam jangka panjang komoditi kedelai tidak dapat menjadi komoditi basis kecuali terjadi perubahan kebijakan khusunya berkaitan dengan kebijakan penambahan areal tanam dan penerapan 
Email : megaaktiva@febi.umkendari.ac.id

Website : https://megaaktiva.umkendari.ac.id/index.php/Jurnal

teknologi produksi yang memungkinkan terjadinya lonjakan dalam produksi kedelai. Hal tersebut sejalan dengan program pemerintah saat ini dimana komoditi kedelai di masukkan sebagai salah satu komoditas yang mendapatkan program khusus melalui kerjasama dengan TNI dalam kerangka peningkatan luas areal tanam.

Komoditi kacang tanah menjadi basis di Kab. Muna, Kolaka Utara, Konawe Utara dan Kota Kendari. Komoditas ini terus dikembangkan secara mandiri oleh masyarakat, meskipun demikian pencapaian peningkatan produktivitas komoditas ini masih etrkendalakarena masih rendashnya penerapan teknologi. Sebagai contoh varietas kacang tanah yang dikembangkan hanya varietas gajah yang telah lama di introdusir BPTP Sultra di Kab. Muna (BPTP Sultra, 2008).

Komoditas ubi kayu menjadi basis di Kab Buton, Muna, Wakatobi, Buton Utara, Konawe Utara dan Kota Kendari, bahkan secara jangka panjang komoditas ini bisa menjadi basis di Kab. Buton dan Kota Kendari. Hal ini tidak terlepas dari pemanfaatan komoditas ini sebagai salah satu pangan pokok selain beras bagi beberapa etnis di Sualwesi Tenggara khususnya etnis Buton dan Muna. Musadar (2016) bahwa pangan lokal kasuami dan kabuto yang merupakan pangan yang diproses dari ubi kayu banyak dikonsumsi oleh etnis Buton dan etnis Muna yang bermukim di Kota Kendari. Etnis lain juga yang bermukim di Kota Kendari banyak yang telah mengkonsumsi jenis pangan lokal tersebut meskipun belum masuk dalam pola pangan harian mereka.

Komoditas peternakan yang dianalisis dalam kajian ini meliputi sapi, kambing, ayam kampung dan ayam petelur. Hasil analisis LQ dan DLQ disajikan pada Tabel 2.

Tabel 2. Hasil Analisis LQ dan DLQ Pada Komoditas Ternak Pada Masing-Masing Kabupaten di Sulawesi Tenggara, 2016

\begin{tabular}{lcccccccc}
\hline \multirow{2}{*}{ Kabupaten } & \multicolumn{2}{c}{ Sapi } & \multicolumn{2}{c}{ Kambing } & \multicolumn{2}{c}{$\begin{array}{c}\text { Ayam } \\
\text { Kampung }\end{array}$} & \multicolumn{2}{c}{ Ayam petelur } \\
\cline { 2 - 10 } & LQ & DLQ & LQ & DLQ & LQ & DLQ & LQ & DLQ \\
\hline Buton & 0,93 & 0,62 & 2,70 & 0,59 & 0,99 & 0,63 & 0,07 & 0,90 \\
\hline Muna & 1,06 & 0,62 & 0,46 & 0,66 & 1,01 & 0,64 & 0,52 & 0,92 \\
\hline Konawe & 2,05 & 0,61 & 1,97 & 0,76 & 0,95 & 0,73 & 1,17 & 0,91 \\
\hline Kolaka & 0,47 & 0,95 & 1,00 & 0,85 & 1,02 & 1,02 & 0,65 & 0,99 \\
\hline Konsel & 1,36 & 1,01 & 0,32 & 1,07 & 0,99 & 0,99 & 1,60 & 0,98 \\
\hline Bombana & 1,17 & 0,52 & 0,62 & 0,49 & 1,01 & 0,48 & 0,35 & 1,05 \\
\hline Wakatobi & 0,51 & 0,70 & 6,56 & 0,73 & 0,86 & 1,20 & 5,82 & 0,46 \\
\hline Kolaka Utara & 0,25 & 1,26 & 0,82 & 1,17 & 1,03 & 0,92 & 0,43 & 1,01 \\
\hline Buton utara & 2,76 & 0,92 & 1,11 & 1,37 & 0,96 & 1,00 & 0,72 & 0,27 \\
\hline Konawe Utara & 1,72 & 1,37 & 2,54 & 0,97 & 0,97 & 1,13 & 0,00 & 1,23 \\
\hline Kota Kendari & 0,31 & 1,06 & 0,76 & 0,94 & 0,91 & 0,78 & 9,07 & 1,12 \\
\hline Kota Bau-Bau & 0,44 & 0,88 & 0,80 & 0,84 & 0,98 & 0,91 & 3,70 & 0,99 \\
\hline
\end{tabular}

Tabel 2 menunjukkan bahwa beberapa komodtas peternakan menjadi basis baik dalam waktu saat ini maupun dalam waktu jangka panjang. Hal ini tentunya ditopang dengan penerapan kebijakan pengembangan komoditas pada masing-masing wilayah. Hasil analisis LQ menunjukkan bahwa komoditas sapi menjadi komoditas basis di Kab. Muna, Konawe, Konawe Selatan, Bombana, Buton Utara dan Konawe Utara. Hal ini 
menunjukkan pengembangan komoditi sapi banyak terkonsentrasi diwilayah-wilayah tersebut dan menjadi sumber pertumbuhan ekonomi di wilayah kabupaten bersangkutan. Namun demikian dalam jangka panjang hanya Kab. Konawe Selatan dan Konawe Utara yang memiliki potensi sapi menjadi komoditas basis. Hal tersebut dapat dilihat dari nilai DLQ $>1$.

Selanjutnya komoditi kambing merupakan komoditi basis di Kabupaten Buton, Konawe, Kolaka, Wakatobi, Buton Utara, dan Konawe Utara. Wilayah-wilayah tersebut selama ini dikenal sebagai sentra pengembangan ternak kambing dan dapat memberikan ekspansi bagi pemenuhan kebutuhan di luar wilayahnya. Meskipun demikian pada wilayah-wilayah tersebut, hanya Kabupaten Buton yangs cara jangka panjang dapat mempertahnakan kambing sebagai komoditas basis. Hal ini tidak terlepas dari potensi sumberdaya yang dimiliki baik biofisik maupun modal sosial masyarakat.

Ayam kampung yang menjadi komoditas yang paling merata pengembangannya di Sulawesi Tenggara dan menjadi basis di Kabupaten Muna, Kolaka dan Kolaka Utara, dengan nilai LQ>1. Namun demikian hanya Kabupaten Kolaka yang memiliki kecederungan menempatkan ayam kampung sebagai komoditas basis dalam jangka panjang. Pengembangan ini tidak terlepas dari dukungan kebijakan pemerintah setempat.

Ayam petelur yang merupakan komoditas relatif "baru" di Sulawesi Tenggara, bahkan beberapa kabupaten belum mengembangkan komoditas tersebut misalnya Buton Utara dan Konawe Utara, komoditas ini mulai dikembangkan awal tahun 2000-an. Komoditas ayam petelur menjadi basis di Kabupaten Konawe, Konawe Selatan, Wakatobi, Kota Kendari dan Kota Bau-Bau. Wilayah tersebut selain Wakatobi memang dikenal sebagai sentra pengembangan komoditas ayam petelur di Sualwesi Tenggara. Wakatobi memiliki nilai LQ>1 menunjukkan bahwa posisi ayam petelur cenderung terkonsentrasi dibandingkan dengan komoditas peternakan lainnya di Kabupaten Wakatobi, meskipun populasi ayam petelurnya relatif rendah, jika dibandingkan dengan populasi ayam petelur di kabupaten lainnya. Kota Kendari memiliki nilai LQ terbesar yaitu 9,07 yang mencerminkan bahwa konsentrasi populasi ayam petelur di Kota Kendari dibandingkan dengan komoditas peternakan lainnya cukup signifikan dan mampu memberikan nilai pertumbuhan yang positif. Hal tersebut diperkuat dengan nilai DLQ>1 yang menunjukkan bahwa komoditas ayam petelur memiliki keunggulan komparatif yang terus meningkat darlam kurun waktu lima tahun terakhir.

Komoditas perkebunan merupakan salah satu subsektor yang memiliki peranan yang cukup penting khususnya dalam penyerapan tenaga kerja maupun sumber pendapatan wilayah. Hasil analisis LQ dan DLQ menunjukkan bahwa komoditas perkebunan menjadi komoditas basis pada beberapa kabupaten. Hal tersebut sebagaimana disajikan pada Tabel 3 yang menunjukkan bahwa dari lima komoditas perkebunan yang dianalisis, masingmasing komoditas menjadi komoditas basis pada kabupaten yang berbeda. Kelapa Dalam menjadi komoditas basis pada sebagian besar kabupaten di Sulawesi Tenggara selain Kabupaten Kolaka dan Kolaka Utara. Hal ini mencerminkan bahwa kelapa dalam memiliki konsentrase pengembangan yang relatif merata di semua kabupaten di Sulawesi Tenggara. Namun demikian dalam jangka panjang komoditas ini nampaknya mengalami reposisi dan mulai kehilangan keunggulan komparatifnya yang ditandai dengan nilai DLQ $<1$. 


\section{JURNAL MEGA AKTIVA}

Email : megaaktiva@febi.umkendari.ac.id

Website : https://megaaktiva.umkendari.ac.id/index.php/Jurnal

Tabel 3. Hasil Analisis LQ dan DLQ Pada Komoditas Perkebunan Pada Masing-Masing Kabupaten di Sulawesi Tenggara, 2016

\begin{tabular}{lcccccccccc}
\hline \multirow{2}{*}{ Kabupaten } & \multicolumn{2}{c}{ Kelapa } & \multicolumn{2}{c}{ Lada } & \multicolumn{2}{c}{ Cengkeh } & \multicolumn{2}{c}{ Jambu Mete } & \multicolumn{2}{c}{ Kakao } \\
\cline { 2 - 12 } & LQ & DLQ & LQ & DLQ & LQ & DLQ & LQ & DLQ & LQ & DLQ \\
\hline Buton & 1,30 & 0,43 & 0,08 & 0,55 & 0,04 & 0,57 & 6,90 & 1,38 & 0,15 & 0,56 \\
\hline Muna & 1,29 & 0,85 & 0,01 & 0,59 & - & 0,57 & 2,66 & 1,29 & 0,80 & 1,05 \\
\hline Konawe & 1,69 & 0,73 & 2,35 & 0,55 & 0,15 & 1,14 & 1,50 & 0,72 & 0,76 & 0,69 \\
\hline Kolaka & 0,95 & 0,58 & 2,29 & 0,46 & 0,90 & 0,55 & 0,14 & 0,40 & 1,10 & 0,74 \\
\hline Konsel & 1,18 & 1,50 & 2,13 & 1,34 & 0,03 & 1,42 & 3,14 & 1,50 & 0,67 & 1,73 \\
\hline Bombana & 3,24 & 0,93 & 0,26 & 0,88 & 0,07 & 0,50 & 0,49 & 0,36 & 0,59 & 0,44 \\
\hline Wakatobi & 4,97 & 0,77 & - & 0,73 & 0,05 & 0,85 & 1,38 & 1,49 & 0,02 & 1,06 \\
\hline $\begin{array}{l}\text { Kolaka } \\
\text { Utara }\end{array}$ & 0,23 & 1,62 & 0,13 & 1,75 & 1,38 & 1,74 & 0,01 & 1,20 & 1,35 & 1,76 \\
\hline $\begin{array}{l}\text { Buton } \\
\text { utara }\end{array}$ & 2,66 & 0,31 & 0,07 & 0,37 & 0,40 & 0,96 & 4,38 & 0,78 & 0,15 & 0,44 \\
\hline $\begin{array}{l}\text { Konawe } \\
\text { Utara }\end{array}$ & 2,35 & 0,95 & 1,81 & 0,63 & 1,16 & 0,65 & 2,75 & 1,12 & 0,34 & 0,97 \\
\hline $\begin{array}{l}\text { Kota } \\
\text { Kendari }\end{array}$ & 1,68 & 0,63 & 3,15 & 0,61 & 0,12 & 0,72 & 3,56 & 0,77 & 0,43 & 1,72 \\
\hline $\begin{array}{l}\text { Kota Bau- } \\
\text { Bau }\end{array}$ & 1,14 & 1,20 & - & 0,67 & 0,07 & - & 5,22 & 1,41 & 0,45 & 1,54 \\
\hline
\end{tabular}

Komoditas lada menjadi basis di Kabupaten Konawe, Kolaka, Konawe Selatan, Konawe Utara dan Kota Kendari, namun demikian komoditas ini dalam jangka panjang cenderung kehilangan tingkat daya saing komparatifnya karena tergantikan dengan komoditas lain. Hal ini ditandai dengan nilai DQLG $<1$, dimana hanya Kabupaten Konawe Selatan yang secara signifikan memberikan pertumbuhan dalam pengembangan lada. Selanjutnya terdapat kabupaten yang tidak mengembangkan komoditas lada yaitu Kabupaten Wakatobi dan Kota Bau-Bau, hal ini tidak terlepas dari potensi sumberdaya alam yang dimiliki, dimana kondisi biofisik lahan di Kabupaten Wakatobi didominasi oleh batu kapur yang telah mengalami pelapukan lanjut.

Komoditas cengkeh menjadi basis di Kabupaten Kolaka Utara dan Konawe Utara. Wilayah tersebut dikenal sebagai sentra pertanaman cengkeh di Sulawesi Tenggara. Namun demikian dalam jangka panjang tingkat komparatif komoditas ini cenderung menurun yang ditandai dengan nilai DLQ <, kecuali Kabupaten Kolaka Utara yang memiliki nilai DLQ > 1 . Hal ini tidak terlepas dari kebijakan jangka panjang pemerintah daerah yang ditunjang oleh kesiapan modal sosial masyarakat dimana komoditas cengkeh menjadi nafas bagi kehidupan pertanian di Kabupaten Kolaka Utara. Lebih lanjut bahwa komodtas cengkeh tidak dikembangkan di Kabupaten Muna dan di kota Bau-Bau nilai DLQ nya tidak terumuskan. Hal ini karena cengkeh pada wilayah tersebut tidak dikembangkan secara berkelanjutan.

Jambu mete yang menjadi ciri khas dari Sualwesi Tenggara menjadi komoditas basis pada sebagian besar kabupaten di Sulawesi Tenggara selain Kabupaten Kolaka, Bombana dan Kolaka Utara. Namun demikian jika dilihat dalam jangka panjang komoditas jambu 


\section{JURNAL MEGA AKTIVA}

Email : megaaktiva@febi.umkendari.ac.id

Website : https://megaaktiva.umkendari.ac.id/index.php/Jurnal

mete juga basis hanya di Kabupaten Buton, Muna, Konawe Selatan, Wakatobi, Konawe Utara dan Kota Bau-Bau. Hal tersebut ditandai dengan nilai DLQ > 1. Daerah tersebut memang memiliki sumberdaya lahan dan iklim yang cocok bagi pengembangan komoditas jambu mete, bahkan di Kabupaten Buton dan Muna komoditas ini telah berkembang menjadi industri rumah tangga.

Kakao merupakan komoditas perkebunan yang cukup besar dikembangkan petani di Sulawesi Tenggara. Komoditas ini menjadi basis di Kabupaten Kolaka dan Kolaka Utara. Hal ini tidak terlepas dari potensi sumberdaya lahan dan iklim yang di wilayah tersebut. Kabupaten Kolaka dan Kolaka Utara memang dikenal sebagai sentra produsesn kakao di Sulawesi, dan menjadi daerah penghasil kakao terbesar di wilayah provinsi.

Komodtas hortikultura yang terdiri dari komoditas buah dan sayuran memiliki peranan yang cukupbesar dalam perolehan PDRB provinsi. Komoditas hortikultura menjadi basis pada beberapa kabupaten. Hal tersebut sebagaimana pada Tabel 4 yag menunjukkan bahwa cabe menjadi komoditas basis pada sebagian besar kabupaten selain Kabupaten Muna, Konawe Selatan dan Kota Bau-Bau. Konsentrasi pengusahaan komoditas cabe besar di kabupaten tersebut terutama dapat dilihat dari nilai LQ yang terbesar yaitu di Kabupaten Kolaka Utara yang nilai LQ sebesar 14,25, yang berarti bahwa produksi cabe sangat dominan dibandingkan dengan komoditas hortikultura lainnya. Dalam jangka panjang komoditas cabe memeliki keunggulan komparatif untuk menjadi komoditas basis di Kabupaten Muna, Kolaka, Buton Utara, Konawe Utara dan Kota Kendari. Hal ini tidak terlepas dari potensi wilayah serta modal sosial ekonomi dan dukungan kebijakan.

Tabel 4. Hasil Analisis LQ dan DLQ Pada Komoditas Hortikultura Pada Masing-Masing Kabupaten di Sulawesi Tenggara, 2016

\begin{tabular}{lllllllll}
\hline & \multicolumn{2}{c}{ Cabe besar } & \multicolumn{2}{c}{ Cabe rawit } & \multicolumn{2}{c}{ jahe } & \multicolumn{2}{c}{ Jeruk } \\
\cline { 2 - 9 } \multicolumn{1}{c}{ Kabupaten } & LQ & DLQ & LQ & DLQ & LQ & DLQ & LQ & DLQ \\
\hline Buton & 0,63 & 1,61 & 0,12 & 0,45 & 1,40 & 0,15 & 0,09 & 0,15 \\
\hline Muna & 1,80 & 1,82 & 3,04 & 2,14 & 0,48 & 0,85 & 2,05 & 1,64 \\
\hline Konawe & 6,65 & 0,52 & 4,33 & 0,54 & 0,60 & 1,28 & 1,30 & 0,65 \\
\hline Kolaka & 2,77 & 1,33 & 2,99 & 1,50 & 0,88 & 0,80 & 0,97 & 1,36 \\
\hline Konsel & 0,32 & 0,64 & 0,32 & 0,66 & 1,05 & 0,80 & 0,98 & 0,47 \\
\hline Bombana & 1,38 & 2,23 & 1,12 & 2,91 & 1,31 & 1,91 & 0,17 & 3,11 \\
\hline Wakatobi & 5,95 & 0,03 & 7,45 & 0,14 & 0,69 & 0,84 & 0,78 & 0,77 \\
\hline Kolaka Utara & 14,25 & 0,45 & 20,60 & 0,87 & 0,07 & 0,66 & 0,41 & 0,83 \\
\hline Buton utara & 4,59 & 1,23 & 4,57 & 0,84 & 0,00 & 0,14 & 2,94 & 0,50 \\
\hline Konawe Utara & 3,25 & 1,22 & 5,63 & 1,17 & 0,17 & 0,16 & 2,47 & 0,26 \\
\hline Kota Kendari & 3,18 & 1,86 & 6,76 & 2,54 & 0,63 & 1,05 & 1,19 & 2,11 \\
\hline Kota Bau-Bau & 0,37 & 1,51 & 0,25 & 2,14 & 1,43 & 0,80 & 0,03 & 1,88 \\
\hline
\end{tabular}

Cabe rawit menjadi komoditas basis di Kabupaten Muna, Konawe, Kolaka, Bombana, Wakatobi, Kolaka Utara, Buton Utara dan Kota Kendari, bahkan di Kabuapten Kolaka Utara memberikan nilai LQ tertinggi yang mencapai 20,60 yang berarti komoditas ini 
terkonsentrasi dibandingkan dengan komoditas lain di wilayah tersebut. Dalam jangka panjang komoditas cabe rawit dapat menjadi komoditas basis di Kabupaten Muna, Bombana, Konawe Utara dan Kota Kendari. Hal tersebut dapat dilihat dari nilai DLQ $>1$. Penguatan komparatif komoditas cabe rawit di wilayah tersebut sangat ditopang oleh potensi sumberdaya alam dan permintaan akan produk tersebut yang terus tumbuh terutama untuk mensuplay wilayah perkotaan, khususnya di kota Kendari.

Komoditas jahe merupakan komoditas yang pengembangannya secara besar-besaran baru dimulai pada beberapa tahun terakhir. Komoditas jahe menjadi basis di Kabupaten Buton, Konsel, Bombana dan Kota Bau-Bau. Permintaan produk ini terutama sebagai bahan baku pembuatan produk jamu dan di antar pulaukan utamanya ke Jawa Timur. Dalam jangka panjang komoditas ini bisa menjadi komoditas basis di Kabupaten Bombana dengan nilai DLQ>1.

Komoditas jeruk menjadi komoditas basis di Kabupaten Muna, Konawe, Buton Utara, Konawe Utara dan Kota Kendari. Wilayah tersebut selama ini dikenal sebagai produsen jeruk terutama Kabupaten Muna dan Konawe. Dalam dalam jangka panjang komoditas dapat menjadi basis di Kabupaten Muna dan Kota Kendari. Hal ini didukung dengan kebijakan pengembangan komoditas tersebut serta potensi sumberdaya lahan dan iklim yang ada di wilayah tersebut.

\section{KESIMPULAN}

Analisis LQ dan DQLQ secara sederhana dapat memetakan status komoditas dalam suatu wilayah apakah menjadi basis dalam kurun waktu saat ini maupun secara berkelanjutan. Status komoditas tersebut akan bergeser sesuai dengan perubahan dinamika penerapan kebijakan, daya dukung infrastruktur wilayah, permodalan maupun peningkatan kapasitas pelaku pertanian. Secara umum komoditas tanaman pangan yang dapat menjadi basis di beberapa wilayah diantaraya adalah jagung, kacang tanah dan ubi kayu, sementara padi dan kedelai hanya menjadi basis saat ini, akan tetapi secara berkelanjutan agan mengalami pergeseran. Selanjutnya komoditas peternakan yang dapat menjadi basis adalah sapi, kambing, ayam kampung dan ayam petelur. Sementara itu komoditas perkebunan yang dapat menjadi basis adalah cengkeh, jambu mete, kelapa dalam, lada dan kakao, meskippun masing-masing wilayah memilikikarakteritisk tersendiri. Komoditas hortikultura yang dapat menjadi basis secara berkelanjutan adalah cabe besar, cabe rawit dan jeruk. Kedepan pengembangan komoditas pertanian yang menjadi sector basis baikd alam waktu saat ini maupun yang memiliki potenis menajdi basis secafra berkelanjutan perlu dioptimlkan dan di dukung dengan penerapan teknologi adaptif yang dapat diterima oleh masyarakat secara social dan memiliki nilai ekonomi yang dapat bersaing.

\section{DAFTAR PUSTAKA}

Abidin Z., Sri Bananiek S. Dan Muhamad Taufiq R. 2013. Profil Kemandirian Pangan Pulau-Pulau Kecil Sulawesi Tenggara Dalam Buku. Membangun Kemandirian Pangan Pulau-Pulau Kecil Dan Wilayah Perbatasan. Iaard Press. Jakarta.

Abidin. 2015. Aplikasi analisis Shift Share pada transformasi sektor pertanian dalam perekonomian wilayah di Sulawesi Tenggara. 
Agustono. 2013. Analisis Sektor Pertanian Ditinjau Dari Peran Terhadap Pertumbuhan Dan Stabilitas Produk Domestik Regional Bruto Di Provinsi Jawa Tengah. Jurnal SEPA : Vol. 9 No. 2. Universitas Sebelas Maret. Surakarta. Hal. 283 - 296.

Arsyad L. 2010. Ekonomi Pembangunan. Yogyakarta: UPP STIM YKPN.

Aqil M dan Rahmi Y.A. 2016. Deskripsi jagung Unggul. Balai Penelitian Tanaman Serealia. Maros.

Balitkabi. 2016. Deskripi Varietas Kacang Tanah 1950 - 2016. Tersedia pada http://balitkabi.litbang.pertanian.go.id/deskripsi-varietas/deskripsi-varietas.html. didownload pada Januari 2017.

Balitkabi. 2016. Deskripi Varietas Ubi Kayu 1978 - 2016. Tersedia pada http://balitkabi.litbang.pertanian.go.id/deskripsi-varietas/deskripsi-varietas.html. didownload pada Januari 2017.

Badan Pusat Statistik. 2013. Statistik Indonesia. Tersedia pada www.bps.indonesia.go.id didownload pada Desember 2014.

BPS Sultra. 2010. Sulawei Tenggara Dalam Angka. Badan Pusat Statistik Sulawesi Tenggara. Kendari.

BPS Sultra. 2016. Sulawesi Tenggara Dalam Angka. Badan Pusat Statistik Sultra. Kendari

Budiharsono, S. 2001. Teknik Analisis Pembangunan Wilayah Pesisir Dan Lautan. Pradnya Paramitha. Jakarta

Dinas Pertanian Sulawesi Tenggara. 2016. Laporan perkembangan luas tanam, produksi dan Produktivitas Padi dan Palawija Tahun 2016. Kendari.

Harjono. 2009. Pola pengembangan sektor perekonomian berbasis agribisnis dalam perspektif pembangunan berkelanjutan di propinsi bali. Ekuitas Vol. 13 No 1. Sekolah Tinggi Ilmu Ekonomi Indonesia. Surabaya. Hal. 61:83

Hendayana. 2003.Aplikasi Metode Location Quotient (LQ) dalam Penentuan Komoditas Unggulan Nasional. Jurnal Informatika. Badan Litbang Pertanian. Jakarta

Hidayat R. 2013. Analisis Komoditas Unggulan Sub Sektor Perkebunan Di Kabupaten Bengkayang Provinsi Kalimantan Barat. Jurnal Social Economic Of Agriculture, Volume 2, Nomor 1, April 2013, Hlm 54-66

Husna N., Irwan N., M.Rozikin. 2013. Analisis Pengembangan Potensi Ekonomi Lokal Untuk Menguatkan Daya Saing Daerah Di Kabupaten Gresik.tersedia pada http//administrasipublik.studentjournal.ub.ac.id. didownload pada januari 2017

Kuncoro, Mudrajad. 2003. Ekonomi Pembangunan Teori, Masalah, Dan Kebijakan. Yogyakarta: UPP AMP YKPN.

Liebman, M., Schulte, L.A., 2015. Enhancing agroecosystem performance and resilience through increased diversification of landscapes and cropping systems. Elementa 3 (1)

Ma'mun D. Dan Irwansyah S. 2013. Analisis Pergeseran Struktur Ekonomi Dan Identifikasi Sektor Potensial Wilayah Pengembangan. Jurnal Social Economic Of Agriculture. Vol 2 No. 1. Hal. 7 - 28

Mustam, Syamsul Anam I, Yusdin dan Z. Abidin. Analisis Rantai Pasok Pangan Pokok di Kota Kendari. Laporan Penelitian. Bappeda Kota Kendari.

Musadar. 2016. Pemberdayaan Pertanian Perkotaan melalui Pengembangan Pakan Lokal SIKKATO mendukung Ketahanan Pangan di Kota Kendari. Desertasi Mahasiwa S3. Fakultas Pertanian Universitas Halu Oleo. Kendari. 


\section{JURNAL MEGA AKTIVA}

Email : megaaktiva@febi.umkendari.ac.id

Website : https://megaaktiva.umkendari.ac.id/index.php/Jurnal

Prawira Y. dan Wahyu. H. 2013. Transformasi struktur ekonomi Kabupaten Siak Tahun 2001 - 2010. Jurnal Ekonomi Vol 21. No 1. Fakultas ekonomi Universitas Riau. Tersedia pada: www.ejournal.unri.ac.id

Puspitawati. L.T. 2013. Analisis perbandingan faktor-faktor penyebab ketimpangan pembangunan antar kabupaten/kota di kawsan Kedungsapur. Economic Development Analysis Journal. Universitas Negeri Semarang. Semarang.

Oktavilia S.2011. Pengembangan Potensi Ekonomi Lokal Daerah tertinggal sebagai upaya Mengatasi Disparitas Pendapatan Natar Daerah di Provinsi Jawa Tengah. Prosiding SnaPP. Universitas Islam Bandung. Bandung

Peneder, M. 2003. Industrial Structure And Aggregate Growth. Structural Change And Economic Dynamics, 14: H:427-448.

Richardson, H.W. 1991. Dasar-Dasar Ilmu ekonomi Regional (Terjemahan) LPFE UI. Jakarta.

Rivai R.S., dan Anugrah I.S. 2011. Konsep dan implementasi pembangunan pertanian berkelanjutan di Indonesia. Forum Penelitian Agroekonomi Vol 29. No 1. Pusat Penelitian dan Pengembangan Pertanian. Bogor. hal $13-25$.

Rusastra, I.W., Pantjar Simatupang dan Benny Rachman.2000. Pembangunan Ekonomi Pedesaan Berlandaskan Agribisnis.Dalam Tahlim Sudaryanto, dkk (Penyunting) Analisis Kebijaksanaan: Pembangunan Pertanian Andalan Berwawasan Agribisnis. Monograph Series N0 23. Pusat Penelitian dan Pengembangan Sosial Ekonomi Pertanian.

Santosa I.M., Agus S., Ratih W. 2013. Analisis Potensi Pengembangan Usaha Peternakan Sapi Perah Dengan Menggunakan Paradigma Agribisnis Di Kecamatan Musuk Kabupaten Boyolali. Buletin Peternakan. Universitas Gadjah Mada. Yogyakarta.

Sudarmono M. 2006. Analisis Transformasi Struktural,Pertumbuhan Ekonomi Dan Ketimpangan Antar Daerah Di Wilayah Pembangunan I Jateng. Tesis Pasca Pasja Sarjana Universitas Diponegoro. Semarang.

Sulistyowati E., Fitria Y., D. S. Rahayu dan Soekadar W. 2012. Pengendalian penggerek buah kakao, Conopomorpha Cramella Snell. Ramah lingkungan. Warta Vol. 24:3. Pusat Penelitian Kopi dan Kakao Indonesia. Jember. Hal 15-20.

Tarigan R., 2009. Ekonomi Regional Teori Dan Aplikasi. PT. Bumi Aksara. Jakarta.

Tilman, D., Balzer, C., Hill, J., Befort, B.L., 2011. Global food demand and the sustainable intensification of agriculture. Proc. Nat. Acad. Sci. 108 (50).

Tscharntke, T., Clough, Y., Wanger, T.C., Jackson, L., Motzke, I., Perfecto, I., Whitbread, A., 2012. Global food security, biodiversity conservation and the future of agricultural intensification. Biol. Conserv. 151 (1), 53-59.

West, P.C., Gerber, J.S., Engstrom, P.M., Mueller, N.D., Brauman, K.A., Carlson, K.M., Siebert, S., 2014. Leverage points for improving global food security and the environment. Science 345 (6194), 325-328. 